\title{
Banning Evolution
}

\author{
William Eric Meikle
}

Published online: 26 August 2011

(C) Springer Science+Business Media, LLC 2011

\begin{abstract}
Laws prohibiting the teaching of human evolution were in effect in some states for over 40 years during the twentieth century. While such laws have been ruled unconstitutional, the opposition to evolution which stimulated their adoption continues as a prominent feature of American culture.
\end{abstract}

Keywords Evolution· Teaching evolution · Legislation

Previous columns in this series from NCSE have discussed such potential obstacles to evolution education as misunderstanding of terms such as "theory" or "homology" and misconceptions about ideas such as "design" or "complexity" (Branch and Mead 2008; Petto and Mead 2009; Mead and Scott 2010; Petto and Mead 2008). Most such obstacles occur at the level of individual students or members of the public. They can, at least in principle, be countered by standard types of education, whether in classrooms or outside them.

Another class of obstacles, however, cannot be easily overcome by individual educators or through straightforward instruction. These are legal obstacles, which may take the form of laws or school board policies or regulations, often at the state level. Since about 1920, attempts to eliminate, limit, or censor the teaching of evolution in the United States via legal mechanisms have taken a number of paths. For an introduction to this topic, see Scott (2009:77164), and for a more detailed historical treatment, see Larson (2003).

W. E. Meikle ( $₫)$

National Center for Science Education, PO Box 9477, Berkeley, CA 94709-0477, USA

e-mail: meikle@ncse.com
Why should teachers be concerned about the history of antievolution legal efforts in the United States? After all, there are no longer any explicit prohibitions against teaching evolution. The "Scopes trial" kind of legal sanction against public school evolution education may seem to be purely of historical interest. But such laws were still on the books in some states well within living memory. In addition, many of the social and cultural factors that led to laws against teaching evolution in the 1920s have persisted and underlie the opposition to evolution that continues at many state and local levels today. Moreover, teachers are generally underinformed about the pertinent legal issues (Moore 2004), which remain very relevant in any local conflict over teaching evolution.

Starting in the 1920s, state laws prohibiting the teaching of evolution, human evolution in particular, were widely proposed, and even adopted in a number of states: Oklahoma, Tennessee, Mississippi, and Arkansas, with Florida adopting a resolution describing the teaching of evolution as "improper and subversive to the best interests of the people" but stopping short of banning it altogether (Larson 2003). The well-known 1925 Scopes trial in Dayton, Tennessee (Larson 1997) was the only significant legal challenge to any of these laws to reach the courts until the 1960s.

Recently, the journal Popular Science has made available online a series of articles about evolution, published between 1923 and 1956, from its archives (http://www.popsci.com/ science/gallery/2011-05/archive-gallery-evolution). Among these is a piece entitled "Beating the Evolution Laws" (Armstrong 1929), which provides a window on contemporary events and the reactions of some teachers and educators in Arkansas and Tennessee to the outlawing of evolution education in those states. The subtitle of this article promises to reveal "How School Teachers in 
Tennessee and Arkansas Spread Prohibited Knowledge by Ingenious Evasions."

Armstrong (1929:18) quotes the first two sections of the Arkansas law enacted through the initiative process in 1928:

Section 1. That it shall be unlawful for any teacher or other instructor in any University, College, Normal, Public School, or other institution of the State, which is supported in whole or in part from public funds derived by State or local taxation to teach the Theory or Doctrine that mankind ascended or descended from a lower order of animals and also it shall be unlawful for any teacher, textbook commission, or other authority exercising the power to select textbooks for above mentioned institution to adopt or use in any such institution a textbook that teaches the doctrine or theory that mankind descended or ascended from a lower order of animals.

Section 2. Be it further enacted that any teacher or other instructor or textbook commission who is found guilty of violation of the Act by teaching the theory or doctrine mentioned in Section 1 hereof, or by using, or adopting any such textbooks in any such educational institution shall be guilty of a misdemeanor and upon conviction shall be fined not exceeding five hundred dollars (\$500.00); and upon conviction shall vacate the position thus held in any educational institution of the character above mentioned or any commission of which he may be a member.

Armstrong seems confident that evolution will continue to be presented in some fashion by many teachers in the affected states. He asks early in the article:

Does this mean that, from now on, all pupils of elementary and high schools and all college and university students in Arkansas will be graduated in complete ignorance of the evolution theory and of what it implies in connection with the origin of man? By no means. On a recent tour of the "antievolution belt" I discovered that the reopening of the schools this fall will find many of the teachers fully prepared to pour the prohibited information into the minds of the young Arkansans in their charge in a variety of ingenious ways. (1929:17)

Armstrong states that all the teachers he interviewed were opposed to the new law and that "a majority of the instructors are determined to "beat' it if they can do so without getting themselves into trouble." How did they plan to do this? One instructor, noting that the law said nothing about the evolution of any organism except for humans, told Armstrong that he explains to his students "that it is illegal to apply to the human race the same method of study and the same drawing of conclusions that we apply to the lower orders of life," and commented, "Rather than dampening their ardor for acquiring knowledge, this seems to create a spirit of investigation that gets results" (Armstrong 1929:18).

Another teacher was planning to inform students that the material on certain specific pages of particular books was illegal due to the antievolution law, and so they would skip those pages. This strategy depended on a distinction between textbooks, clearly mentioned in the law, and reference books or other types, not so mentioned. A university professor suggested that he could tell students to consult reference books in the library to learn about evolution without breaking the law. And of course students would still be free to purchase their own books about evolution, even to order them from out of state if necessary, for their own private use.

In Tennessee, the 1925 law under which John T. Scopes was convicted prohibited teaching human evolution, without mentioning textbooks. Some of Armstrong's Tennessee informants stated that they could present evolution while complying with the law by reading "directly from the text, without making any comment on what they read." Armstrong quotes a Tennessee attorney's opinion that they would not thus be teaching "unless they are commenting and explaining."

While it is impossible to determine from Armstrong's article, written only a few months after the Arkansas initiative had been passed, to what extent and in what fashion evolution was actually taught in the state before and

\footnotetext{
$\overline{{ }^{1} \text { In Kitzmiller }}$ v. Dover (400F. Supp. 2d 707 [M.D. Pa. 2005]), the case establishing the unconstitutionality of teaching intelligent design in the public schools, however, a similar defense of a pro-intelligent design and antievolution disclaimer mandated by the Dover Area School Board was unsuccessful. In his decision, Judge John E. Jones III wrote:

Throughout the trial and in various submissions to the Court, Defendants vigorously argue that the reading of the statement is not "teaching" ID but instead is merely "making students aware of it." We disagree.

Dr. [Brian] Alters, the District's own science teachers, and Plaintiffs Christy Rehm and Steven Stough, who are themselves teachers, all made it abundantly clear by their testimony that an educator reading the disclaimer is engaged in teaching, even if it is colossally bad teaching. ... Dr. Alters rejected Dover's explanation that its curriculum change and the statement implementing it are not teaching. The disclaimer is a "mini-lecture" providing substantive misconceptions about the nature of science, evolution, and ID which "facilitates learning." In addition, superintendent [Richard] Nilsen agrees that students "learn" from the statement, regardless of whether it gets labeled as "teaching."
} 
after 1928, we do know the general course of American evolution education in subsequent years. Although Scopes's conviction was overturned on a technicality by the Tennessee Supreme Court, and there were no similar prosecutions of teachers accused of violating any state law against teaching evolution, the controversy surrounding the trial impelled textbook publishers to downplay evolution: "the teaching of evolution in the high schools - as judged by the content of the average high school biology textbooks-declined after the Scopes trial" (Grabiner and Miller 1974:832, emphasis in original) until the 1960s.

In the 1960s, thanks to the federal government's infusion of funds to science education, evolution was returning to the textbooks. Although the antievolution laws of the Scopes era were still on the books, they were not actively enforced, and there were even attempts to repeal them: the Tennessee legislature repealed the state's antievolution law in 1967. The decisive judicial ruling establishing the unconstitutionality of laws banning the teaching of evolution came in the following year, in the Supreme Court's decision in Epperson v. Arkansas (393 U.S. 97 [1968]), which invalidated the Arkansas antievolution law. In the court's decision, Justice Abe Fortas wrote, "The State's undoubted right to prescribe the curriculum for its public schools does not carry with it the right to prohibit, on pain of criminal penalty, the teaching of a scientific theory or doctrine where that prohibition is based upon reasons that violate the First Amendment."

Subsequent antievolution laws, proposed or adopted, have no longer prohibited teaching evolution, but have required or allowed balancing evolution with "creation science" or "intelligent design" (Scott 2009:97-164) or, more recently, have retreated to what Branch and Scott (2009:96) describe as the "standard fallback strategy for undermining the teaching of evolution: misrepresenting evolution as scientifically controversial while remaining silent about what they regard as the alternative," using "a flurry of labels and slogans-'teach the controversy,' 'critical analysis,' and 'academic freedom."' Since 1968, formal proposals to ban the teaching of evolution outright have been few and far between.

Unfortunately, there are still teachers who seem to have imposed a ban on themselves: Berkman and others (2008) report that $2 \%$ of high school biology teachers responding to their survey omit the topic of evolution altogether, with as many as $17 \%$ omitting the topic of human evolution altogether. Moreover, Berkman and Plutzer (2011) estimate that $60 \%$ of high school biology teachers-whom they dub "the cautious $60 \%$ "- "fail to explain the nature of scientific inquiry, undermine the authority of established experts, and legitimize creationist arguments, even if unintentionally."

We may not have advanced as far from the days of banning evolution as we would like to believe. But the courage of teachers who have stood up for the integrity of science education-like Scopes; like those interviewed by Armstrong, who sought to evade the strictures of what they regarded as a law motivated by ignorance; like Epperson, who agreed to challenge the Arkansas law in court in 1965; and like the teachers in Dover, Pennsylvania, who refused to read the pro-intelligent design and antievolution disclaimer mandated by their school board in 2004should give us hope for the future.

\section{References}

Armstrong OK. Beating the evolution laws. Popular Science. 1929;115(3):17-9,134-5. http://www.popsci.com/science/gallery/ 2011-05/archive-gallery-evolution?image $=3$

Berkman MB, Plutzer E. Defeating creationism in the courtroom, but not in the classroom. Science. 2011;333(6016):404-5.

Berkman MB, Pacheco JS, Plutzer E. Evolution and creationism in America's classrooms: a national portrait. PLoS Biol. 2008;6(5): e124

Branch G, Mead LS. "Theory" in theory and practice. Evo Edu Outreach. 2008;1(3):287-9.

Branch G, Scott EC. The latest face of creationism. Sci Am. 2009;300 (1):92-9.

Grabiner JV, Miller PD. Effects of the Scopes trial: was it a victory for evolutionists? Science. 1974;185(4154):832-7.

Larson EJ. Summer for the gods: the Scopes trial and America's continuing debate over science and religion. New York: Basic Books; 1997.

Larson EJ. Trial and error: the American controversy over creation and evolution. 3rd ed. New York: Oxford University Press; 2003.

Mead LS, Scott EC. Problem concepts in evolution part I: purpose and design. Evo Edu Outreach. 2010;3(1):78-81.

Moore R. How well do biology teachers understand the legal issues associated with the teaching of evolution? Bioscience. 2004;54 (9):860-5

Petto AJ, Mead LS. Misconceptions about the evolution of complexity. Evo Edu Outreach. 2008;1(4):505-8.

Petto AJ, Mead LS. Homology: why we know a whale is not a fish. Evo Edu Outreach. 2009;2(4):617-21.

Scott EC. Evolution vs. creationism: an introduction. 2nd ed. Berkeley: University of California Press; 2009. 